소 FASN 유전자 변이의 연관불균형과 한우 도체형질에 미치는 영향

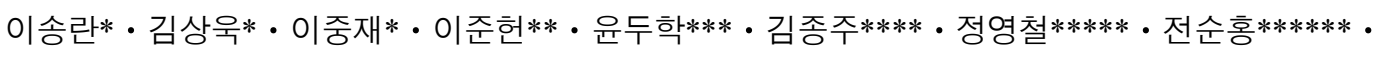

최재원****** · 김내수*·김관석*

충북대학교 농업생명환경대학 응용생명환경학부 축산학과*, 충남대학교 농업생명과학대학 동물자원과학부**, 농촌진흥청 국립축산과학원***, 영남대학교 생명공학부****, 정피엔씨연구소*****, 충청북도 축산위생연구소******

\title{
Characterization of the Bovine FASN Gene Variation for Carcass and Beef Quality Traits in Hanwoo
}

Songlan Li*, Sang Wook Kim*, Jung Jae Lee*, Jun Heon Lee**, Duhak Yoon***, Jong Joo Kim****, Young Chul Jeong*****, Soon Hong Jeon******, Jae Won Choi******, Nae Su Kim* and Kwan Suk Kim*

College of Agriculture, Life and Environment Sciences, Chungbuk National University, Cheongju 361-763, Korea*,

College of Agriculture, and Life Sciences, Chungnam National University, Daejeon 305-764, Korea**,

Division of Animal Genomics and Bioinformatics, National Institute of Animal Science, Suwon 441-706, Korea***, School of Biotechnology, Yeungnam University, Gyeongsan 712-749, Korea****, Jung Pork \& Customer Institute,

Kyounggi 272-5, Korea*****, Institute of Livestock and Veterinary Research, Chungbuk, Korea******

\begin{abstract}
Fatty acid synthase (FASN) is a multi-functional enzyme with a central role in the synthesis of long-chain fatty acid and has been considered as a positional candidate gene for BTA 19 quantitative trait loci (QTL) affecting milk-fat content and fatty acid composition. In this study, we sequenced the FASN gene in several cattle breeds including Hanwoo and imported beef cattle, and identified novel DNA polymorphisms and their linkage relationship in Hanwoo. We found a significant frequency difference of the FASN (AF285607) g.17924 A $\rightarrow$ G polymorphism between Hanwoo (70\%) and other breeds and this polymorphism has been known for an association with fatty acid composition in Angus.

Furthermore, by direct DNA sequencing in 18 unrelated Hanwoo, we identified 27 SNPs including nine novel variations in the FASN gene. Among 27 SNPs identified in the FASN gene, four SNPs were further genotyped in 100 Hanwoo and 96 imported beef cattle, and analyzed for haplotype construction and association with beef quality traits. We performed haplotype block and linkage disequilibrium studies using four selected SNPs. Two different haplotype blocks (block A: g.10568 C $\rightarrow$ T and g.11280 G $\longrightarrow$ A; block B: g.13125 $\mathrm{C} \rightarrow \mathrm{T}$ and g.17924 $\mathrm{G} \rightarrow \mathrm{A}$ ) were constructed and the block A in particular had a very high $\mathrm{r} 2(0.936)$, which indicated a nearly complete linkage disequilibrium existed between the g.10568 $\mathrm{C} \rightarrow \mathrm{T}$ and $\mathrm{g} .11280 \mathrm{G} \rightarrow \mathrm{A}$ polymorphisms. A total of four major haplotypes (frequency $>0.05$ ) were identified with the four polymorphisms including TATG $(0.36)$, CGCG (0.31), CGTA (0.19) and TACG (0.06).

Statistical association analysis revealed that the g.10568 $\mathrm{C} \rightarrow \mathrm{T}$ and g.11280 $\mathrm{G} \rightarrow \mathrm{A}$ polymorphisms in the FASN were significantly associated with meat color $(\mathrm{P}=0.004)$ and texture $(\mathrm{P}=0.0114)$. The g.13125 $\mathrm{C} \rightarrow \mathrm{T}$ and $\mathrm{g} .17924 \mathrm{G} \rightarrow \mathrm{A}$ polymorphisms in the FASN were also significantly associated with back-fat thickness and quantity index $(\mathrm{P}=0.0179$ and 0.0495 , respectively). Our findings suggested that the FASN gene polymorphisms may be used for determining the (unsaturated) fatty acid contents and carcass trait in the Hanwoo beef.
\end{abstract}

(Key words: FASN, SNPs, HRM assay, Hanwoo, Beef quality)

\section{I. 서 론}

쇠고기의 품질은 육색, 지방색, 연도 및 근내지방도 등 에 의해서 좌우되며 (Hocquette 등, 2005; Geay 등, 2001)이 중 근내지방은 쇠고기의 풍미와 연도를 증가시켜 육질등
급결정에 있어 중요한 척도가 되고 있다 (Tatum 등, 1982). 쇠고기의 근내지방을 구성하는 중요한 성분인 중성지방의 지방산조성은 크게 포화지방산과 불포화지방산으로 구성 되어진다. 올레인산 (C18:1n-9)은 쇠고기내 가장 많은 비율 을 차지하는 불포화지방산의 한 종류로 고기내 함량은 풍

Corresponding author: Dr. Kwan Suk Kim, Department of Animal Science, Chungbuk National University, Cheongju, Chungbuk, 361-763 Korea. Tel: 82-043-261-2547, Fax: 82-043-273-2240, E-mail: kwanskim@chungbuk.ac.kr 
미와 정 $(+)$ 의 상관관계에 있다고 알려져 있고, 근내지방 도가 증가하면 지방산의 조성비율의 변화와 함께 올레인 산 비율이 증가한다고 보고되었다 (Smith 등, 2006).

지방산합성효소(FASN)는 소의 19번 염색체에 위치한 42 개의 exon으로 이루어진 유전자이며, 우유의 지방산조성 에 영향을 미치는 후보유전자로 보고되었다 (Roy 등, 2005; Roy 등, 2006). 특히 Morris 등 (2007)은 소 Jersey / Limousin 의 전형매 교배를 통해서 염색체 19 번 $60 \sim 90 \mathrm{cM}$ 사이에 유 지방과 지방산 조성에 큰 영향력을 미치는 QTL 영역이 FASN 유전자와 동일한 위치에 있다고 보고하였다. Zhang 등 (2008)은 미국의 육우인 앵거스 집단을 이용하여 Exon 39 번에 위치한 g.17924 G>A와 Exon 42번에 위치한 g. $18663 \mathrm{G}>\mathrm{C}$ 의 두 개의 단일염기 변이 다형성에 대한 연 구를 하였는데 g. $17924 \mathrm{G}>\mathrm{A}$ 의 $\mathrm{GG}$ 형과 g. $18663 \mathrm{G}>\mathrm{C}$ 의 $\mathrm{CC}$ 형 두 유전자형은 미트리스산 (myristic acid; $\mathrm{C} 14: 0$ )과 팔 미트산(palmitic acid; C16:0)과 같은 포화지방산 함량과는 관련이 없지만, 올레인산 (C18:1)과 총 단가불포화지방산 함량과 밀접한 관계를 가지고 있다고 보고 하였다.

Choi 등 (2008)은 한우와 화우 및 앵거스 집단을 대상으 로 지방산 분석을 한 결과 포화지방산 중, 팔마틴산 (C16:0)은 앵거스 집단이 한우와 일본 화우교잡집단보다 다소 높은 경향이 있었으며, 불포화 지방산인 팔미토레인 산(16:1) 및 올레인산 (C18:1)의 함량은 근내지방도가 높은 한우와 화우집단이 앵거스 집단보다 많이 함유되어 있는 것으로 보고되었다.

따라서 본 연구에서는 쇠고기의 육질에 중요한 결정요 인인 지방산 함량에 영향을 미치는 것으로 알려진 소 FASN 유전자의 염기서열과 염기변이간의 연관특성을 분 석하였을 뿐만아니라, 발굴된 한우에서의 FASN 유전자의 변이가 한우육의 육질특성에 어떠한 영향을 미치는지를 연구하였다.

\section{ㅍ. 재료 및 방법}

\section{1. 공시재료와 DNA 추출}

본 연구는 일반 한우사육농가에서 2007년도 10월부터 12월 사이에 출하된 한우비육우중 경기도 평택시에 위치 한 (주)평농에서 도축된 100 두의 등급판정결과 (축산물등 급판정소 제공)를 이용하였는데, 냉도체 판정 후 등심조직 에서 샘플을 채취하여 Genomic DNA Prep Kit(Solgent, Korea)를 이용하여 DNA 를 추출하였다.

조사된 형질로는 한우 등급판정결과의 도체형질인 도체 중, 등지방두께, 배장근단면적, 육량지수, 육량등급, 근내 지방도, 육색, 지방색, 조직감, 성숙도, 육질등급, 육량등급 및 성별 등 12 개 항목에 대하여 실시하였으며 농림부 고 시 (축산물 등급판정 세부기준, 제 2004-66호)의 측정방법 을 이용하였다. 미국산 육우집단의 Genomic DNA는 Michigan Cattlemen's Association (MCA)/Michigan State
University (MSU) Farm에서 온 샘플이며, 해당되는 자료들 은 http://www.micattlemen.org/ 사이트에서 찾아볼 수 있다.

\section{FASN 유전자 변이 탐색을 위한 PCR 및 염기서열 분석}

본 실험을 위하여 제작된 프라이머는 모두 $\mathrm{NCBI}$ GenBank accession number AF285607을 참조하여 Oligo 6 (Molecular Biology Insights, Cascade, CO, USA) 프로그램을 이용하여 제작하였다 (Table 1).

유전자내 단일염기 변이를 조사하기 위하여 미국 미시 건 샘플중에 Herford, Angus, Simmental 품종을 교잡하여 생산된 비육육우 4 개 샘플의 $\mathrm{DNA}$ 를 혼합하여 3 개 그룹을 만들고 한우집단에서는 임의로 선택한 2 개의 샘플의 DNA 를 혼합하여 4 개 그룹을 만들어서 총 7 개의 혼합 DNA 샘 플을 주형 DNA 로 이용하였다. DNA 증폭을 위해 사용된 PCR 기계는 PTC-200 themocycler (MJ Research, Watertown MA, USA)이며, DNA 중합효소는 h-Taq polymerase (Solgent, Korea)를 사용하였다. PCR 반응조건은 template DNA $25 \mathrm{ng}$, primer $0.01 \mathrm{uM}$, dNTP $5 \mathrm{mM}, 10 \mathrm{XPCR}$ buffer $2.5 \mathrm{ul}$, 그 리고 h-Taq DNA polymerase를 0.625 units를 넣어 최종 반 응액 $25 \mathrm{ul}$ 을 이용하였다. 반응조건은 최초 $95^{\circ} \mathrm{C}$ 에서 15 분 간 예비가열 한 후 $95^{\circ} \mathrm{C}$ 에서 20 초 동안 변성시키고, 각 Primer에 대응하는 annealing 온도 (Table 1)에서 20초 그리 고 $72^{\circ} \mathrm{C}$ 에서 30 초 합성 (extension) 시키는 총 40 사이클 반 복증폭하고 $72^{\circ} \mathrm{C}$ 에서 5 분 마지막 합성단계 (final extension) 를 수행하고 DNA 증폭을 중단하였다. 증폭한 산물들은 $4 \mathrm{ul}$ 를 취하여 모두 $2 \%$ agarose gel에서 $100 \mathrm{mv}$ 전압에서 20 분간 전기영동을 통해 확인하였다.

증폭산물은 Geneclean turbo kit (MP Biomedicals, USA)를 이용하여 정제한 후 Applied Biosystems 3730 DNA sequencer (PE Applied Biosystems, USA)를 이용하여 염기서 열분석을 수행하였다. 얻어진 염기서열들은 Sequencher ver 4.7 (Gene codes, version 4.7, Ann RBOR, MI)을 사용하여 4 품종 사이에서 나타나는 단일염기변이를 조사하였다.

\section{High Resolution Melt (HRM) 시스템을 이용한 유전 자형 결정.}

발굴된 g.10568 C> T, g.11280 G> A, g.13125 C> T, g.17924 G>A 등 4개의 단일염기변이 $(\mathrm{SNPs})$ 분석은 Roror-Gene ${ }^{\mathrm{TM}} 6000$ (Corbett) Real-Time PCR 기계를 이용하 여 High Resolution Melt (HRM) 시스템을 이용하여 한우 집단 100 두에서 유전자형 결정을 수행하였다. Zhang 등 (2007)이 보고한 FASN-Ex39-G17924A 단일염기변이는 미 국 미시간 육우집단에서도 유전자형 결정을 실시하였다. $\mathrm{HRM}$ 시스템을 이용할 목적으로 제작된 Primer는 Table 2 에 나열하였다.

PCR 반응조건은 염기서열 분석을 통해 유전자형 알고 
Table 1. Primer used in these experiments

\begin{tabular}{|c|c|c|c|}
\hline Primer Name & Primer Sequence $\left(5^{\prime}-3^{\prime}\right)$ & Annealing TM & Product Size(bp) \\
\hline FASN-9-1804-F & CССАACCTGCACTТCСАCAАC & \multirow{2}{*}{60} & \multirow{2}{*}{844} \\
\hline FASN-9-1804-R & CGTCCTTCCGATGCCTGTC & & \\
\hline FASN-12-15-F & ATCGGAAGGACGCAGGAGACC & \multirow{2}{*}{62} & \multirow{2}{*}{1171} \\
\hline FASN-12-15-R & GCCCACGTTGCTGAGGAAGA & & \\
\hline FASN-16-19-F & TCTCAGGCGTCTCCAAGGTCT & \multirow{2}{*}{62} & \multirow{2}{*}{1105} \\
\hline FASN-16-19-R & CGGAGCTGGCCTCAAGGATA & & \\
\hline FASN-20-22-F & CATCACCGCCATCTACATCCA & \multirow{2}{*}{60} & \multirow{2}{*}{1448} \\
\hline FASN-20-22-R & AAGGCCCACCCACCGATT & & \\
\hline FASN-23-26-F & GACGTGAGGTCGCCCAACTC & \multirow{2}{*}{60} & \multirow{2}{*}{1000} \\
\hline FASN-23-26-R & AGGAATCGGCCAGGATGTTCT & & \\
\hline FASN-27-30-F & TGGACTGAGAGGGCAAGA & \multirow{2}{*}{58} & \multirow{2}{*}{972} \\
\hline FASN-27-30-R & CGGCTGACCCTGGCAGAG & & \\
\hline FASN-31-34-F & CACCATCCGCCTGTATCCTCA & \multirow{2}{*}{58} & \multirow{2}{*}{944} \\
\hline FASN-31-34-R & CCGRCGGGCAARRCACCT & & \\
\hline FASN-36-38-F & TGCGGTCCCACCCTCATAAC & \multirow{2}{*}{58} & \multirow{2}{*}{904} \\
\hline FASN-36-38-R & CAGATGGACAAGCCCTGT $=$ ACCT & & \\
\hline TE-a-F ${ }^{+}$ & AGAGCTGACGGACTCCACAC & \multirow{2}{*}{55} & \multirow{2}{*}{697} \\
\hline TE-a-R ${ }^{+}$ & CTGCATGAAGAAGCACATGG & & \\
\hline TE-b-F ${ }^{+}$ & CTCGCACACCTTCGTGATG & \multirow{2}{*}{57} & \multirow{2}{*}{472} \\
\hline TE-b-R ${ }^{+}$ & CACGTTGCCGTCCTAGGTAG & & \\
\hline TE-c-F ${ }^{+}$ & CGCTCACTGTCCTGTCCTAC & \multirow{2}{*}{55} & \multirow{2}{*}{373} \\
\hline TE-c- $R^{+}$ & GCTGTGAATAATACTAAGGATGGA & & \\
\hline${\mathrm{MSC}-\mathrm{F}^{+}}^{+}$ & AGAGCTGACGGACTCCACAC & \multirow{2}{*}{55} & \multirow{2}{*}{382} \\
\hline MSC-R $^{+}$ & GCCGATGCACTCGATGTAG & & \\
\hline
\end{tabular}

* All primers were based on the bovine FASN sequence NCBI GenBank accession number AF285607.

${ }^{+}$Primers were referenced from Zhang et al., 2008.

있는 Control DNA 3두와 유전자형을 모르는 주형 DNA

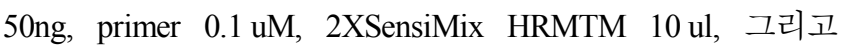
EvaGreen $0.5 \mathrm{ul}$ 를 넣어 최종 반응액 $20 \mathrm{ul}$ 을 이용하였다. 반응조건은 최초 $95^{\circ} \mathrm{C}$ 에서 15 분간 예비가열 한 후 $95^{\circ} \mathrm{C}$ 에 서 30 초 동안 변성시키고, 각 Prmier에 대응하는 annealing 온도 (Table 2)에서 30 초 그리고 $72^{\circ} \mathrm{C}$ 에서 40 초 합성 (extension)시키는 총 40 사이클 반복증폭하고 $72^{\circ} \mathrm{C}$ 에서 5 분 마지막 합성단계 (final extension)를 수행하고 HRM 시 스템을 이용하여 유전자형 결정을 하였다.

\section{4. 통계 분석}

$\mathrm{SNPAlyze}^{\mathrm{TM}}$ (version 7.0) 프로그램을 구동한 후 결정되 어진 각 haplotype 별로 FASN 유전자내의 임이 의 두 마 커 간 연관 불균형 (Linkage Disequilibrium)를 아래와 같은 r-square 방법을 이용하였다.

$$
\mathrm{r}^{2}=\sum_{i j} \mathrm{~h}_{\mathrm{ij}} \frac{\left(h_{i j}-p_{i} q_{j}\right)^{2}}{p_{i}\left(1-p_{i}\right) q_{j}\left(1-q_{j}\right)}
$$

여기서 $\mathrm{p}_{\mathrm{i}}$ 는 첫 번째 마커 대립인자 $i$ (예: 1st SNP allele
' 1 ')의 빈도를 말하며 $\mathrm{q}_{j}$ 는 두 번째 마커 대립인자 $j$ 의 (예: 2nd SNP allele ' 1 ') 빈도를 가리킨다. 따라서 마커 한 쌍 당 총 4 개의 haplotype이 $(11,12,21,22)$ 존재한다. hij는 두 마커에 있는 $i j$ hapltoype의 빈도를 가리킨다.

조사된 경제형질 측정치에 대한 유전자형의 효과를 추 정하기 위해 SAS 9.1 Package/PC를 이용하여 일반선형모 형 (GLM) 분석을 하였으며, 유전자형의 효과가 유의한 형 질들에 대해 최소 유의차 검정으로 평균간 차이에 대한 유 의성을 조사하였다. 통계분석에 이용한 모형은 다음과 같다.

$$
\mathrm{Y}_{i j k}=\mu+\mathrm{S}_{i}+\mathrm{G}_{j}+\mathrm{e}_{i j k}
$$

여기서, $\mathrm{Y}_{i j k}, \mu, \mathrm{S}_{i}, \mathrm{G}_{j}, \mathrm{e}_{\mathrm{ijk}}$ 는 각각 형질의 측정치, 전체 평균, 성별효과, 개체의 유전자형 효과, 임의오차를 나타 내고 있다. 
Table 2. Primer designs for HRM assay

\begin{tabular}{|c|c|c|c|}
\hline Primer Name & Primer Sequence (5'-3') & Annealing TM & Product Size(bp) \\
\hline FASN-18-F & TGAGAATGGCAACCTGATCGC & \multirow[b]{2}{*}{55} & \multirow[b]{2}{*}{180} \\
\hline FASN-18-R & AGAGCTTGGGGTTGGGATCT & & \\
\hline FASN-21-F & CCACAGTGGCCGACGTG & \multirow{2}{*}{55} & \multirow{2}{*}{135} \\
\hline FASN-21-R & AACTTCTCCAGGATGGGCACC & & \\
\hline FASN-24-F & GCCCTGACCCCCTCAAC & \multirow{2}{*}{55} & \multirow{2}{*}{149} \\
\hline FASN-24-R & GCAGGAACATTGGGCTGTCAA & & \\
\hline FASN-39-F & ACCTTGACACGGCTCAACTC & \multirow{2}{*}{58} & \multirow{2}{*}{132} \\
\hline FASN-39-R & CACTGTGGCCATAGGTGGG & & \\
\hline
\end{tabular}

* The four SNPs were HRM genotyped in the Hanwoo for association analysis $(n=100)$

염기서열 상으로 볼 때 $\mathrm{FASN}$ 은 42개의 exon과 41개의 intron 으로 이루어졌다(Fig. 1). 본 연구에서는 FASN 유전 자내의 염기서열에서 한우 품종과 미국산 육우 3 개 집단 에서 단일 염기 변이를 탐색하였다. 8개 Primer 쌍을 이용 해 exon9부터 Intron 38번까지 염기서열분석을 수행하였고, exon 39 42 변이 분석은 Zhang 등 (2008)이 사용한 TE-a$\mathrm{F} / \mathrm{R}, \mathrm{TE}-\mathrm{b}-\mathrm{F} / \mathrm{R}, \mathrm{TE}-\mathrm{c}-\mathrm{FR}, \mathrm{MSC}-\mathrm{F} / \mathrm{R}$ 등 4 쌍의 Primer 들을 이용하였다.

Table 3에서 보는 바와 같이 모두 한우와 미국 육우 샘 플에서 15 개의 $\mathrm{SNP}$ 를 발견하였다. 본 실험에서 수행한 소 FASN 유전자 연기서열 결과를 기존에 보고된 염기서 열을 http://www.ensembl.org/과 http://www.ncbi.nlm.nih.gov/ projects/SNP/에서 비교 하였을때 6개의 $\mathrm{SNP}$ 는 이미 보고 되었던 $\mathrm{SNP}$ 인 것을 확인하였고, 나머지 9 개의 $\mathrm{SNP}$ 들은 새로 발굴된 것으로 확인되었다. 그리고 총 15 개의 발견 된 $\mathrm{SNP}$ 들 가운데 6개 $\mathrm{SNP}$ 는 intron에서, 9개는 Exon 부
위에 위치하였고, 2개의 g.13125 C> T, g.17924 G>A $\mathrm{SNP}$ 가 단백질 아미노산 구조에 변화를 주는 Missense $\mathrm{SNP}$ 로 확인되었다 (Table 3).

2. 한우와 미국육우 집단에서의 FASN 유전자 변이의 빈도 조사.

본 실험에서는 한우집단 시료 100 두를 이용하여 선정한 4 개의 SNP에 대한 유전자형을 결정하였다 특히 FASN 유 전자내 Exon 39번 위치한 g.17924 G>A 변이 빈도를 추 정하기위해 한우와 미국육우 집단을 이용하여 유전자형 결정을 하였는데 g.17924A 대립유전자는 상대적으로 높은 Palmitic acid(포화지방산)의 함량과 낮은 Oleic acid(불포 화 지방산)의 함량에 영향을 주는 유전자형으로써 미국육 우집단에서 A 대립유전자 빈도는 0.41 로 관찰되었지만 한 우집단에서는 0.22 로 보다 낮게 관찰되었고, Oleic acid함
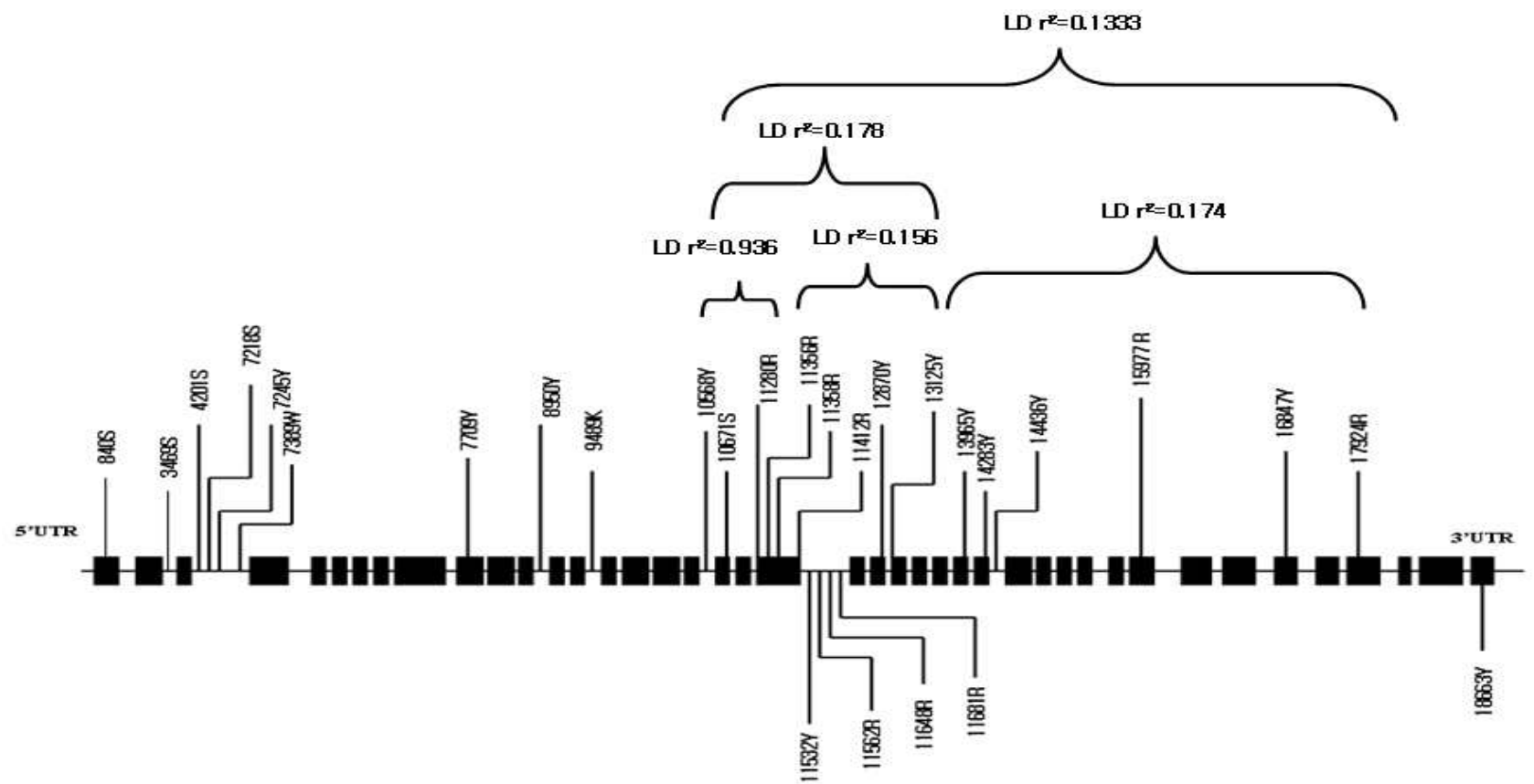

Fig. 1. SNP detection and Linkage disequilibrium of FASN on chromosome 19. (In total length is $19.7 \mathrm{~kb}$ and exons are marked as black block). LDs were estimated usingSNPAlyze ${ }^{\mathrm{TM}}$ program. 
Table 3. Discovery SNPs of bovine FASN in this study

\begin{tabular}{|c|c|c|c|}
\hline & $\begin{array}{c}\text { SNP } \\
\text { position** }\end{array}$ & Location & Amino acid change \\
\hline \multirow{12}{*}{ NCBI } & $840 \mathrm{~S}$ & Exon 1 & Synonymous \\
\hline & $3469 \mathrm{~S}$ & Intron2 & - \\
\hline & $4201 \mathrm{~S}$ & Intron3 & - \\
\hline & $7218 \mathrm{~S}$ & Intron3 & - \\
\hline & $7245 \mathrm{Y}$ & Intron3 & - \\
\hline & $7383 \mathrm{~W}$ & Intron3 & - \\
\hline & $8950 \mathrm{Y}$ & Intron 12 & - \\
\hline & $9489 \mathrm{~K}$ & Intron 14 & - \\
\hline & $10671 \mathrm{~S}$ & Exon 19 & Synonymous \\
\hline & $14283 \mathrm{Y}$ & Exon 27 & Synonymous \\
\hline & $15977 \mathrm{R}$ & Exon 34 & Synonymous \\
\hline & $16847 \mathrm{Y}$ & Exon 37 & Synonymous \\
\hline & $* 7709 \mathrm{C}>\mathrm{T}$ & Exon 10 & Synonymous \\
\hline \multirow{8}{*}{$\begin{array}{l}\text { New } \\
\text { SNP }\end{array}$} & $* 10568 \mathrm{C}>\mathrm{T}$ & Intron 18 & - \\
\hline & $* 11280 \mathrm{C}>\mathrm{T}$ & Exon 21 & Synonymous \\
\hline & $* 11356 \mathrm{~A}>\mathrm{G}$ & Exon 21 & Synonymous \\
\hline & $* 11412$ A $>G$ & Intron 21 & - \\
\hline & $* 11562 A>G$ & Intron 21 & - \\
\hline & $* 11648$ A $>G$ & Intron 21 & - \\
\hline & $* 11681 \quad A>G$ & Intron 21 & - \\
\hline & $* 14436$ C $>\mathrm{T}$ & Intron 28 & - \\
\hline & $11532 \mathrm{C}>\mathrm{T}$ & Intron 21 & . \\
\hline \multirow{5}{*}{$\begin{array}{c}\text { Reported } \\
\text { SNP }\end{array}$} & $12870 \mathrm{C}>\mathrm{T}$ & Exon 23 & Synonymous \\
\hline & $13125 \mathrm{C}>\mathrm{T}$ & Exon 24 & Missense Tyr $>$ His \\
\hline & $13965 \mathrm{C}>\mathrm{T}$ & Exon 27 & Synonymous \\
\hline & $17924 G>A$ & Exon 39 & Missense $\mathrm{Thr}>$ Ala \\
\hline & $18663 \mathrm{C}>\mathrm{T}$ & Exon 42 & Synonymous \\
\hline
\end{tabular}

\footnotetext{
* NEW SNPs

** Nucleotide position are numbered according to the first base of FASN gene as it appears in GenBank accession number AF285607
}

량을 증가시키는 것으로 알려진 $\mathrm{G}$ 대립유전자의 한우집단 에서의 빈도 0.78 로 매우 높게 분포되었다 (Table 4).
3. 한우집단에서 FASN 유전자 변이의 연관 불균형 및 반수체 구역 분석

발굴된 $\mathrm{SNP}$ 가운데 총 4 개의 $\mathrm{SNP}$ 를 선별하여 $\mathrm{SNP}$ 간의 연관성을 분석한 결과, g. $10568 \mathrm{C}>\mathrm{T}$ 와 g. $11280 \mathrm{G}>\mathrm{A}$ 마 커 사이의 연관비평형 (Linkage disequilibrium)은 $\mathrm{r}^{2}=0.94$ 로 매우 유의적으로 높게 나타났다. 또한 g. 13125 C> T와 g.17924 G>A의 $\mathrm{LD}\left(\mathrm{r}^{2}=0.1\right)$ 도 유의적인 수준을 나타냈다. 반수체구역 (haplotype block)은 연관 불균형 $\mathrm{r}^{2}(0.1)$ 유의수 준에 따라 계산된 반수체 구역 $\mathrm{A}$ 와 반수체구역 $\mathrm{B}$ 로 나누 었으며, 반수체구역 $\mathrm{A}$ 의 반수체형 $1(\mathrm{C}+\mathrm{G})$ 의 빈도는 0.54 의 빈도로 가장 높은 빈도로 나타났으며, 반수체형 $2(\mathrm{~T}+\mathrm{A})$ 빈도도 0.45 의 빈도로 높게 나타났으며, 높은 $\mathrm{LD}$ 값 $(0.94)$ 로 알 수 있듯이 g. 13125 C는 g.11280 G와 완전한 $\mathrm{LD}$ 를 가지고 있어서 반수체 구역 $\mathrm{A}$ 의 반수체형 $3(\mathrm{~T}+\mathrm{G})$ 의 빈도 는 0.01 이하로 매우 낮은 것을 관찰 할 수 있었다, 이와 는 다르게 반수체 구역 $\mathrm{B}$ 의 반수체형 $1(\mathrm{~T}+\mathrm{G}), 2(\mathrm{C}+\mathrm{G})$, $3(\mathrm{~T}+\mathrm{A})$ 들의 빈도는 각각 $0.4,0.38,0.2$ 이하로 나타났다. 반수체 구역 $\mathrm{A}$ 의 반수체형들과 반수체 구역 $\mathrm{B}$ 의 반수체형 들의 조합의 빈도는 Table 5 에 나타났다.

\section{4. 한우 FASN 유전자형의 도체형질 연관성 분석}

한우집단 시료 100 두를 이용하여 연관비평형으로 존재 하는 4개의 SNP에 대한 유전자형을 결정하였으며, Table 6 은 유전자형에 따른 형질과의 연관성을 나타낸다. 등지방두 께와 육량지수에 유의적으로 연관된 좌위는 Thioesterase (TE) domain 영역의 Exon39 번에 존재하는 g.17924 G>A 변이이었는데 유의성이 높은 상가적 (additive) 효과를 나타 내었다. $\mathrm{GG}$ 유전자형이 가장 낮은 등지방두께와 높은 육 량지수를 보였고, GA 유전자형이 그 다음으로 높았으며, $\mathrm{AA}$ 유전자형은 가장 낮은 근내지방 함량을 나타내었다.

또한 Intron 18번에 존재하는 g.10568 C> T와 Exon21번 에 존재하는 $\mathrm{g}, 11280 \mathrm{G}>\mathrm{A}$ 는 높은 연관비평형 존재로 육 색과 조직감 형질에 유의적인 연관성이 있는 것으로 나타 났다. g. $10568 \mathrm{C}>\mathrm{T}$ 의 $\mathrm{CC}$ 형은 육색과 조직감이 $\mathrm{CT}$ 형과 TT형보다 높게 나타났다(Table 6). g,11280 G>A 역시

Table 4. Genotypes and minor allele frequencies of 4 FASN gene polymorphisms in Hanwoo. Minor allele frequency was calculated with alleles with lower frequency of each genotype

\begin{tabular}{cccccccccc}
\hline \multirow{2}{*}{ SNP name } & \multirow{2}{*}{ Position } & $\begin{array}{c}\text { AA } \\
\text { change }\end{array}$ & \multicolumn{2}{c}{ Genotype (N. of cattle) } & \multicolumn{2}{c}{$\begin{array}{c}\text { Total } \\
\text { N. of cattle }\end{array}$} & $\begin{array}{c}\text { Minor allele } \\
\text { frequency }\end{array}$ & Heterozygosity & $\begin{array}{c}\text { HWE } \\
\text { P-value }\end{array}$ \\
\hline \hline $10558 \mathrm{Y}$ & Intron18 & - & $\mathrm{CC}(27)$ & $\mathrm{CT}(55)$ & $\mathrm{TT}(17)$ & 99 & 0.449 & 0.555 & 0.222 \\
$11280 \mathrm{R}$ & Exon21 & Silent & $\mathrm{GG}(27)$ & $\mathrm{GA}(55)$ & $\mathrm{AA}(17)$ & 99 & 0.449 & 0.555 & 0.222 \\
$13125 \mathrm{Y}$ & Exon24 & His-Tyr & $\mathrm{CC}(16)$ & $\mathrm{CT}(45)$ & $\mathrm{TT}(39)$ & 100 & 0.385 & 0.450 & 0.385 \\
$17924 \mathrm{R}$ & Exon39 & Ala-Thr & $\mathrm{GG}(62)$ & $\mathrm{GA}(29)$ & $\mathrm{AA}(7)$ & 98 & 0.219 & 0.295 & 0.178 \\
$17924 \mathrm{R}^{*}$ & Exon39 & Ala-Thr & $\mathrm{GG}(32)$ & $\mathrm{GA}(43)$ & $\mathrm{AA}(16)$ & 91 & 0.403 & 0.470 & 0.301 \\
\hline
\end{tabular}

* US beef cattle genotype: The favorable GG frequency was only $35 \%$ in US beef cattle. 
Table 5. LDs and Haplotype Blocks in the Hanwoo FASN gene

A) LDs among FASN polymorphisms

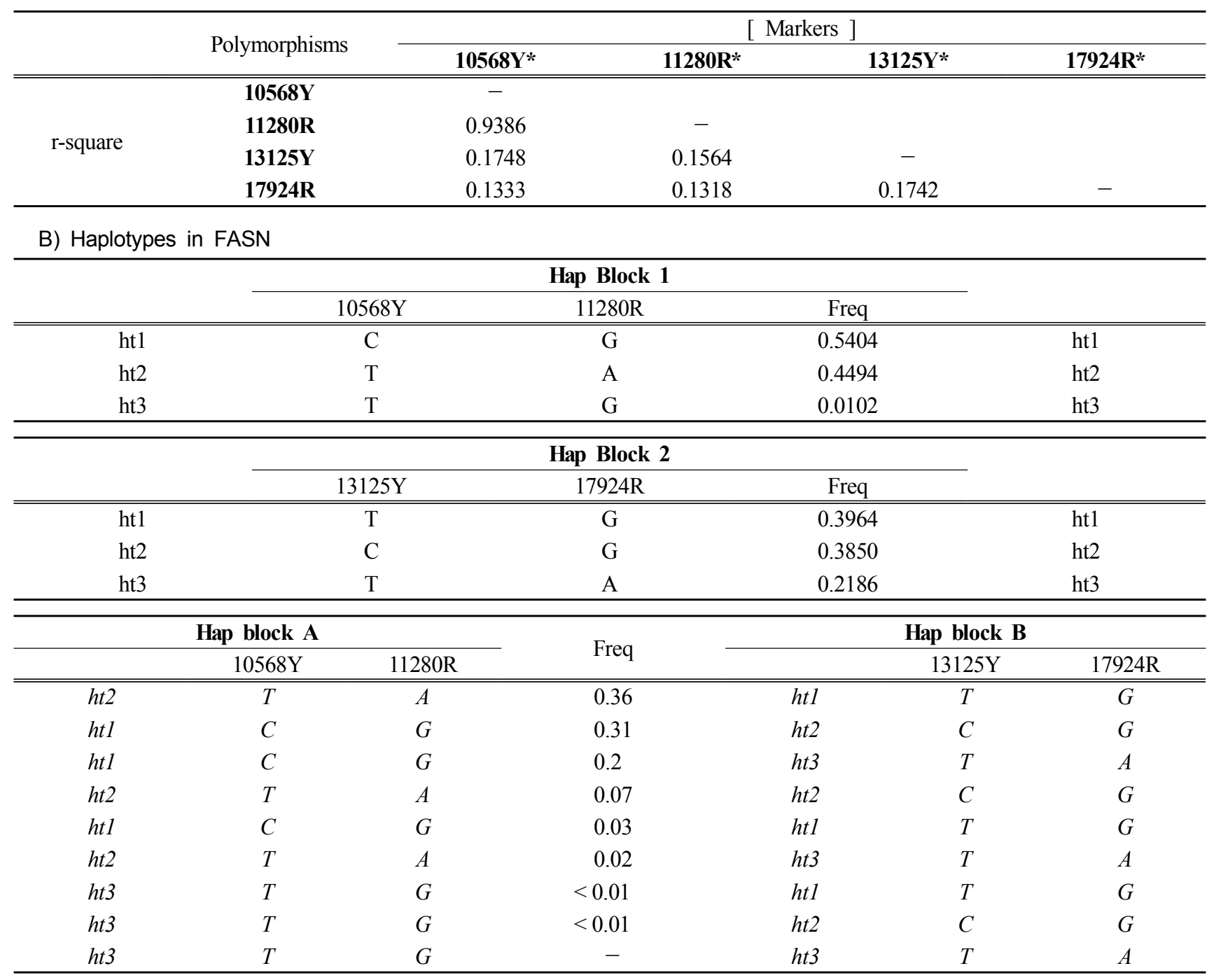

A) LDs among FASN polymorphisms., B). Haplotypes in FASN., Asterisks (*) indicate polymorphisms genotyped in Korean native cattle $(n=100)$

Table 6. Association analyses of 4 polymorphisms of FASN gene with carcass traits among Korean native cattle

\begin{tabular}{|c|c|c|c|c|c|c|c|}
\hline Gene-SNP & Phenotypic trait & Genotypic & c least squares mea & ns ( SE ) & P-value & $\begin{array}{l}\text { Additive } \\
\text { P-value }\end{array}$ & $\begin{array}{l}\text { Dominant } \\
\text { P-value }\end{array}$ \\
\hline \multirow{2}{*}{$\begin{array}{l}\text { FASN-10568 (C/T) } \\
\quad(\mathrm{n}=99)\end{array}$} & Meat color & $5.120(0.091)^{\mathrm{e}}$ & CT : $4.941(0.070)^{\mathrm{e}, \mathrm{f}}$ & TT : $4.575(0.110)^{\mathrm{f}}$ & 0.0004 & 0.0122 & 0.4311 \\
\hline & Text & $2.059(0.041)$ & СТ : 1.980 (0.032) & TT : $2.099(0.050)$ & 0.0501 & 0.3212 & 0.0187 \\
\hline \multirow{2}{*}{$\begin{array}{l}\text { FASN-11280 (G/A) } \\
\quad(n=99)\end{array}$} & Meat color & $5.120(0.091)^{\mathrm{e}}$ & GA : $4.941(0.070)^{\mathrm{e}, \mathrm{f}}$ & AA : $4.575(0.110)^{\mathrm{f}}$ & 0.0004 & 0.0101 & 0.4554 \\
\hline & & $2.093(0.045)^{\mathrm{a}}$ & GA : $1.975(0.035)^{\mathrm{b}}$ & $\mathrm{AA}: 2.095(0.055)^{\mathrm{a}}$ & & 0.3043 & 0.0044 \\
\hline \multirow{2}{*}{$\begin{array}{c}\text { FASN-13125 }(\mathrm{C} / \mathrm{T}) \\
\quad(\mathrm{n}=100)\end{array}$} & Backfat thickness (mm) & $\mathrm{CC}: 6.154(0.670)$ & CT : $7.684(0.458)$ & TT : $7.696(0.463)$ & 0.0912 & 0.1344 & 0.5477 \\
\hline & Quantity & $\mathrm{CC}: 69.543(0.598)$ & CT : $68.097(0.409)$ & TT : $68.263(0.413)$ & 0.0879 & 0.0330 & 0.0420 \\
\hline \multirow{3}{*}{$\begin{array}{c}\text { FASN-17924 (G/A) } \\
(\mathrm{n}=98)\end{array}$} & Backfat thickness (mm) & $6.877(0.405)^{\mathrm{a}}$ & GA : $7.892(0.530)^{\mathrm{a}, \mathrm{b}}$ & AA : $9.446(0.958)^{\mathrm{b}}$ & 0.0179 & 0.0147 & 0.2655 \\
\hline & Quantity Index & $68.824(0.367)^{\mathrm{a}}$ & GA : $67.929(0.480)^{\mathrm{ab}}$ & AA : $66.955(0.867)^{\mathrm{b}}$ & & 0.0021 & 0.3010 \\
\hline & Meat color & $4.848(0.073)$ & GA : $5.012(0.096)$ & AA : $5.170(0.174)$ & 0.0967 & 0.0198 & 0.0290 \\
\hline
\end{tabular}

Significance level: ${ }^{\mathrm{a}, \mathrm{b}} 0.05 ;{ }^{\mathrm{c}, \mathrm{d}} 0.01 ;{ }^{\mathrm{e}, \mathrm{f}} 0.005$. 
g.10568 C> T와 높은 연관비평형 상태이기 때문에 같은 유의적인 효과를 관찰 할 수 있었다. 따라서 육색이 좋으 며, 등지방두께는 얇고 육량이 많은 높은 개체들은 g.10568 C > T + g.17924 G>A $(\mathrm{C}+\mathrm{G})$ 반수체형을 가져야 하는데 그 빈도는 사용된 한우집단에서 0.34 로 나타났다.

\section{IV. 고 찰}

본 연구에서는 쇠고기의 지방산의 함량과 조성에 영향 을 주는 것으로 보고된 FASN 유전자를 이용하여 한우품 종에서의 염기서열을 분석하여 유전자내의 변이와 도체형 질과의 연관성을 분석하였다, 고기의 지방산 조성가운데 포화지방산과 불포화지방의 비율은 인간의 대사성질환에 연관이 있다고 알려져 있는데 특히 포화지방산은 중성지 방산 수치를 증가시키고 이로 인해 동맥경화의 위험이 높 아지며 심장병, 뇌졸중 등 혈관질환이 발생하게 된다. 이 에 반하여 불포화 지방산은 혈소판의 응집을 억제하여 혈 전형성을 막는 효과가 있기 때문에 심장질환으로 인한 사 망률을 줄여주는 것으로 보고되었다 (Alo 등, 1999). 그동 안 한우육에서는 올레인산의 함량이 다른 품종의 쇠고기 보다 높은 것으로 알려져 있지만 그 유전적인 요인에 대 해서는 알려진 바가 없었는데, 한우집단에서 FASN 유전 자의 Oleic acid 함량을 증가시키는 것으로 알려진 g.17924G 대립유전자의 빈도 $(0.86)$ 는 매우 높게 관찰되었 으며, g.17924G 대립유전자는 또한 등지방두께를 줄여서 육량지수를 높이는 것으로 나타났다. 또한 g.10568 C> T 와 Exon21번에 존재하는 $\mathrm{g}, 11280 \mathrm{G}>\mathrm{A}$ 는 높은 연관비평 형 존재로 육색과 조직감 형질에 영향을 주는 것으로 나 타나, FASN 유전자 내의 이러한 변이는 해당형질의 DNA 마커로 활용될 수도 있을 것으로 사료된다.

지방산합성효소 $(\mathrm{FASN})$ 는 동물이나 효모의 지방산 합성 효소계로서 다효소복합체로 acetyl기 전이 및 축합, 3ketoacyl 환원, 탈수 그리고 enjoy 환원을 일으키는 각 효 소가 한 조로 구성된 복합체가 dimer로 이루어진 복합성 효소이며 아세틸-CoA와 말로닐-CoA를 합성하여 긴 사슬 의 지방산 사슬을 만든다(Wakil 등, 1989; Smith 등, 1994). FASN 유전자는 지방산합성의 완성에 관여하며, 포 유동물의 우유 생성기작 및 고기의 지방산 조성에 중요한 영향을 미치는 후보유전자로 잘 알려져 있다 $(\mathrm{Lin}$ 과 Smith 등, 1978; Wakil 등, 1983). FASN 유전자내의 exon 39번부 터 42 번까지의 부분은 $\mathrm{TE}$ 효소를 코딩하는 염기서열 부분 인데 Pazirandeh 등 (1989)은 C14 acyl-ACP와 C16 acyl-ACP 가 $\mathrm{TE}$ 의 작용산물임을 증명하였다. Roy 등 (2006)과 Morris 등 (2007)의 연구에 의해 TE 부분에 존재하는 g.17924 G>A의 유전자 변이가 포유동물의 우유 속에 함 유하는 자방산 조성에 연관이 있다고 보고하였고, Zhang 등 (2008)은 g.17924 G>A 유전자 변이의 유전자형 GG 형은 고기내 Oleic acid(불포화 지방산) 함량을 높이고, Palmitic acid(포화지방산)는 낮추는 반면, $\mathrm{AA}$ 형을 가진 쇠
고기는 Oleic acid(불포화 지방산)의 함량이 상대적으로 낮고, Palmitic acid(포화지방산)은 높은 것으로 보고하였 다. Oleic acid $(\mathrm{C} 18: 1)$ 증가는 근내지방의 증과와 밀접한 관계가 있으며, 올레인산과 고기의 풍미는 양의 상관관계 에 있다고 이미 오래전에 알려져 있다 (Waldman 등, 1968; Westerling과 Hedrick 등 1979).

본 연구에서는 또한 국내한우집단과 미국산 육우집단에 서 포화지방산 및 불포화 지방산이 함량에 직접적인 연관 이 주는 것으로 알려진 FASN 유전자의 exon 39번 g.17924 $\mathrm{G}>\mathrm{A} \mathrm{SNP}$ 에 관한 대립유전자 빈도를 조사하였는데, 미 국의 육우집단에서는 A 대립유전자형 (0.65)이 많이 나타 나는 반면 우리나라 한우 집단에서는 $\mathrm{G}$ 대립유전자의 개 체 (0.71)가 현저히 많은 것으로 나타났다. Zhang 등 (2008) 의 보고에 따르면 g17924 G>A 변이는 미국의 육우인 Angus 집단에서는 $\mathrm{AA}$ 형과 $\mathrm{GG}$ 형이 고루 분포되어 있음을 보고하였는데, $\mathrm{GG}$ 형의 개체들이 올레인산이 포함된 불포 화지방산의 함량이 높아서 건강에 이로운 고급쇠고기를 생산하는데 $\mathrm{GG}$ 형의 개체를 선발하는 것이 도움이 되는 것으로 보고하였다. 또한 올레인산은 쇠고기내 가장 많은 비율을 차지하는 지방산으로써 근내지방도가 증가하면 지 방산의 조성비율의 변화와 함께 올레인산 비율이 증가한 다고 보고되었다 (Smith 등, 2006).

FASN 유존자의 exon9-exon24 영역에 대한 염기서열 분 석을 통해 15 개의 SNPs를 확인하였으며, 그 중에서 intron 18-exon39번 사이의 4개의 SNPs (g.10568 C> T, g.11280 $\mathrm{G}>\mathrm{A}, \mathrm{g} .13125 \mathrm{C}>\mathrm{T}, \mathrm{g} .17924 \mathrm{G}>\mathrm{A}$ )들은 연관 불균형 상 태를 이루고 있었다. 또한 g.10568 C> T와 g.11280 G>A 은 육색과 고기의 조직감에 고도의 연관성이 관찰되었고, g.17924 G>A 변이는 등지방두께에 연관성이 관찰되었다. 따라서 한우집단 100 두 중 육색이 좋으며, 등지방두께는 얇 고 육량이 많은 높은 개체들은 g.10568 C> T+g.17924 G $>\mathrm{A}(\mathrm{C}+\mathrm{G})$ 반수체형을 가진 개체로 판단되며 그 빈도는 0.313 나타내었다. 그 외 반수체형들의 빈도는 $0.364(\mathrm{~T}+\mathrm{G})$ 와 $0.199(\mathrm{C}+\mathrm{A})$ 등의 결과를 관찰하였다. 본 연구에 이용 된 한우샘플들은 일반한우사육농가들에서 평농(주)에 출하하 여 도축된 시료를 이용한 것으로서 형질별 유전적인 능력 (육종가)을 정확히 추정하는데 필요한 혈연정보자료가 없지 만, 상이한 사양관리아래에서 출하된 한우개체들을 대상으 로 연구한 것으로써 작은 유전적 효과를 발굴하기 어려운 샘플집단이다. 따라서 이러한 한우집단에서 발견된 유의적 수준의 FASN 유전자형 효과는 실질적으로 매우 흥미로우 며, 동일한 사양관리와 연령에서 나타날 수 있는 FASN 유 전자형에 따른 형질에 미치는 영향과 밝혀진 3 개의 반수 체형들의 정보를 이용하여 추가적인 연구가 이루어 져야 할 것이다. 따라서 이번 연구를 통해 FASN 유전자는 한우 의 육질을 조절하는 자방산과의 밀접한 연관성이 있으며 외래품종보다 우수한 육질요인을 가지고 있음을 확인하였 고, 한우집단에서의 다양하고 차별적인 육질관련 유전요인 을 밝히는데 중요한 기반을 제공하는 것으로 사료된다. 


\section{V. 요 약}

소 염색체 19번에 존재하는 유지방 함량 및 지방산 조 성에 영향을 미치는 양적경제 형질 유전자 좌위에서 발견 된 지방산 합성 효소인 FASN 유전자는 포화지방산과 불 포화지방산의 함량을 조절하는 강력한 후보유전자이다. 본 연구에서 FASN 유전자의 g.17924 A> G 변이를 한우 집단과 미국산 육우 집단에서 분석하였고 그 결과는 한우 에서는 $\mathrm{GG}$ 형의 개체빈도가 $(71 \%)$ 로 매우 높았으며, 미국 산육우에서는 $\mathrm{GG}$ 형 빈도는 불과 $(35 \%)$ 밖에 되지 않았다. 한우 품종에서 FASN 유전자의 염기서열 분석을 하여 27 개의 단일염기 변이를 발견 하였고, 그 중 9 개는 본 연구 에서 처음으로 밝혀지는 단일염기 변이이다. 한우 집단 100 두와 수입우 집단 96에 대하여 유전자형 분석을 수행 한 결과, FASN 유전자 내의 4개의 단일염기 변이의 연관 불평형 및 반수체 구역을 연구하였다. g.10568 C> T와 g.11280 G>A 단일염기 변이의 다형성은 한우집단에서 고기의 육색 $(\mathrm{P}=0.004)$ 과 고기의 조직감 $(\mathrm{P}=0.0114)$ 에 고도 의 유의성이 통계적인 분석에 의하여 나타났다. 그리고 g.13125 C> T와 g.17924 G>A 다형성은 등지방두께 및 육량지수에 유의성을 관찰할 수 있었다 $(\mathrm{P}=0.0179,0.0495)$. 이상의 결과는 소 FASN 유전자 내의 변이들이 한우집단 의 불포화 지방산 함량과 도체 형질에 연관성은 차별화된 고급한우육을 생산하기 위한 중요한 DNA 마커로써 활용 가치가 있을 것으로 사료된다.

\section{VI. 사 사}

본 연구는 2009년 농림수산식품부 농림기술개발사업의 지원 (과제명: 한우 육량 - 육질 조기 선발용 DNA Kit 산업 화 기술 개발)에 의하여 수행되었으며, 이송란과 이중재는 2단계 BK21사업의 장학금 수혜를 받았습니다.

\section{VII. 인 용 문 헌}

1. Alo, P. L., Visca, P., Marci, A., Mangoni, A., Botti, C. and Di Tondo, U. 1996. Expression of fatty acid synthase (FAS) as a predictor of recurrence in stage I breast carcinoma patients. Cancer. 77:474-482.

2. Choi, C. B., Shin, H. U., Lee, S. O., Kim, S. I., Jung, K. K., Choi, C. W., Baek, K. K., Lunt, D. V. and Smith, S. T. 2008. Comparison of Cholesterol Contents and Fatty Acid Com- position in longissmus of Hanwoo, Angus and Wagyu Crossbred Steers. K. J. Anim. Sci \& Techol. 50:519-526.

3. Geay, Y., Bauchart, D., Hocquette, J. F. and Culioli, J. 2001. Effect of nutritional factors on biochemical, structural and metabolic factors on of muscles in ruminant, consequences on dietic value and sensorial qualities of meat. Reprod. Nutr. Dev. 41:1-26.

4. Hocquette, J. F., Richardson, R. I., Prachardson, R. I., Prache,
S., Medale, F., Duffy, G. and Scollan, N. D. 2005. The future trends for research on quality and safety of animal product. Italian J. Anim. Sci. 4:49-72.

5. Lin, C. Y. and Smith. S. 1978. Properties of the thioesterase component obtained by limited trypsinization of the fatty acid synthetase multienzyme complex. J. Biol. Chem. 253:1954-62.

6. Morris, C. A., Cullen, N. G., Glass, B. G., Hyndman, D. L., Manley, T. R., Hickey, S. M., McEwan, J. C., Pitchford, W. S., Bottema, C. D. K. and Lee, M. A. H. 2007. Fatty acid synthase effects on bovine adipose fat and milk fat. Mamm. Genome, 18:64-74.

7. Pazirandeh, M., Chirala, S. S., Huang, W. Y. and Wakil, S. J. 1989. Characterization of recombinant thioesterase and acyl carrier protein domains of chicken fatty acid synthase expressed in Escherichia coli. J. Biol. Chem. 30:18195-18201.

8. Roy, R., Zaragoza, P., Gautier M., Eggen, A. and Rodellar, C. 2005. Radiation hybrid and genetic linkage mapping of two genes related to fat metabolism in cattle: fatty acid synthase (FASN) and glycerol-3-phosphate acyltransferase mitochondrial (GPAM). Anim Biotechnol. 16:1-9.

9. Roy, R., Ordovas, L., Zaragoza, P., Romero, A., Moreno, C., Altarriba, J. and Rodellar, C. 2006. Association of polymorphisms in the bovine FASN gene with milk fat content. Anim. Genet. 37:215-218.

10. Smith, S. 1994. The animal fatty acid synthase: one gene, one polypeptide, seven enzymes. FASEB. J. 8:1248-1259.

11. Smith, S. B., Lunt, D. K., Chung, K. Y., Choi, C. B., Tume, R. K. and Zembayashi, M. 2006. Adiposity, faty acid composition, and delta- 9 desaturase activity during growth in beef cattle. Anim. Sci. J. 77:478-486.

12. Tatum, J. D., Smith, G. C. and Carpenter, Z. L. 1982. Interrelationships between marbling, subcutaneous fat thickness, and cooked beef palatability. J. Anim. Sci. 43:777-784.

13. Wakil, S. J., Stoops, J. emK. and Joshi, V. C. 1983. Fatty acid synthesis and it's regulation. A. R. Biochem. 52:537-579.

14. Wakil, S. J. 1989. Fatty acid synthase, a proficient multifunctional enzyme, Biochem 28:4523 - 4530.

15. Waldman, R. C., Suess, G. G. and Brungardt, V. H. 1968. Fatty Acids of Certain Bovine Tissue and Their Association with Growth, Carcass and Palatability Traits. J. Anim Sci. 27:632-635.

16. Westerling, D. B. and Hedrick, H. B. 1979. Fatty acid composition of bovine lipids as influenced by diet, sex and anatomical location and relationship to sensory characteristics. J. Anim. Sci. 48:1343-1348.

17. Zhang, S., Knight, T. J., Reecy, J. M. and Beitz, D. C. 2008. DNA polymorphisms in bovine fatty acid synthase are associated with beef fatty acid composition. Anim. Genet. 39:62-70.

18. 농림부. 2004 . 축산물 등급판정 세부기준. 농림부고시 제 2004-66호.

(접수일자 : 2009. 4. 24. / 수정일자 : 2009. 5. 28. /

채택일자 : 2009. 6. 8.) 